\title{
Government Policy of District Bintan Increasing The Ability Of Village In Managing The Authority
}

\author{
Afrizal \\ Maritim Raja Ali Haji University \\ Tanjung Pinang, Indonesia \\ Afrizal.umrah@gmail.com
}

(Study of Malang Rapat Village Authority in Managing Tourism Potential)

\begin{abstract}
The village hasauthority to regulate and manage the affairs of government, the interests of the local community by community initiatives, the right of origin, and /or traditional rights recognized and respected in the governance system of the Republic of Indonesia. One of the potential that exists in the village of Malang Rapat is tourism. The existing condition indicates that the village has not maximal manage the potential to improve the welfare of rural communities. How the function of local government that has direct control of the village to create policy that encourage the village to be able to manage its authority. The purpose of this study to identify what was done by the local government to the village, why the village government has not been able to maximize the authority of the village. Concept / theory that approached is the policy and the authority of the village. While the methods used is descriptive qualitative. The results of the analysis obtained that the local government especially the Bintan District government is not maximized in conducting guidance to the village of Malang Rapat.
\end{abstract}

\section{Keywords-Government Policy, Village, Authority}

\section{PRELIMINARY}

The authority of the village is an important element that is attached to a community institution named village. As mandated in the Village Law No. 6 of 2014 on the village of governing authority of the village. The authority includes the village; authority in the field of rural governance, the implementation of rural development, rural community development, empowerment of rural communities based on the initiative of the community, the right to the origins and customs of the village.

The spirit of the law is how the village could manage his own household, able to realize the people's welfare by utilizing the potential that exists in both the village natural resources and human resources. With the authority of the village and especially the authority to empower rural communities based on community initiatives, the right of origin and customs provide good news and opportunities for the village government for the welfare of rural communities.

The authority of the village is the point of departure of the achievements of these objectives. However, the question of when the village government has not been able to maximize the village authority mandated by law. So much potential villages that can not be fully utilized and the impact on rural welfare. This problem is caused by various problems one of which is the authority of the village have not been optimized as well. The village government has not been able to and understand how to utilize and run the village authority mandated by law. As a result, the condition of the village remains always marginalized compared to the city.

These conditions encourage the government to change the perspective of the development in Indonesia, where the government pay more attention to rural development. This can be seen from the central government through the program nawacita one of the program states that Indonesia build from the periphery to strengthen these areas and villages within the framework of the Unitary Republic of Indonesia. The seriousness of the government can also be seen from the government's efforts in improving the country's independence the local economy with the issuance of Law No. 6 of 2014 on the village and the village fund program rolled out with a very large nominal not been obtained previously.

The condition of the villages in Indonesia today is very far from a good situation. There are many villages in Indonesia are categorized as backward village, only a few villages that have been out of status for the underdeveloped villages self-sufficient and advanced toward the village. Based on the data potential of the village in 2014 it obtained the category of villages in Indonesia with the Village Building on 73709 Index are:

Table. 1.1

Calculation of Index Village Building

\begin{tabular}{|l|l|c|c|}
\hline No. & \multicolumn{1}{|c|}{ Type Village } & Number & Percentage \\
\hline 1 & $\begin{array}{l}\text { Village Very } \\
\text { Disadvantaged }\end{array}$ & 13453 & $18: 25 \%$ \\
\hline 2 & Villages & 33592 & $45.57 \%$ \\
\hline 3 & $\begin{array}{l}\text { Rural } \\
\text { Developing }\end{array}$ & 22882 & $31.04 \%$ \\
\hline 4 & Desa Maju & 3,608 & $4.89 \%$ \\
\hline 5 & $\begin{array}{l}\text { Independent } \\
\text { Village }\end{array}$ & 174 & $0,24 \%$ \\
\hline
\end{tabular}

Data source: index Indonesia build Books 2015 
Improvement well-being of rural communities through community-based tourism program is one of the strategies and efforts that can be done by the village government to improve the welfare of society. The tourism sector is a labor-intensive sector, the economic benefit is very much could be generated from this sector such as accommodation, lodging, restaurants, transportation. The sector is also very labor-intensive, for Bintan district just as the data obtained in the year 2013 BPS labor absorption of $18.03 \%$ of the tourism sector. It is natural for this sector to be a priority in improving the welfare of rural communities.

There are some problems of tourism in the province of Riau Islands according to the Strategic Plan of the Department of Tourism Riau islands include some external factor that becomes the problem of tourism in the province of Riau Islands, among others: as much as 19 Isla Leader in Riau Islands Province (Karimun 2, Batam 4, Bintan 1, Natuna 7 , Anambas 5), which directly borders with neighboring countries to be a challenge to increase social welfare. Mileage inter- district / city and inter-district mileage long enough is also a challenge for the provision of marine transportation infrastructure to speed up the travel time. Implementation of the ASEAN Economic Community (AEC), among others:

1. Lack of implementation of marine tourism events to attract tourists to visit in Riau Islands;

2. The low quality of nautical tourism facilities and infrastructure to support the tourist attraction in the Riau Islands;

3. The low capacity of nautical tourism human resources management related to tourism, and cooperation with travel support businesses;

4. They still lack the means of transportation for supporting accessibility to area attractions;

5. There is still a lack of tourism promotion both at national and international levels.

Exploiting the potential of the village is very likely carried out by the village government with the authority inherent in the institution. Bintan regency of Riau Islands province is one region in Indonesia which has a tremendous potential especially natural tourism potential. Most of the coast of Bintan Island is an area of white sand has tremendous tourism potential.

Along the coast of Bintan island there are many traditional villages in direct contact with the tourist beach area. Villagers living near the beach in direct contact and interact with the tourists who visit and stay at the beach area. This condition is prolonged so that it can maximize the potential positive effects to the people who live on the seashores, especially in improving the local economy. As contained in the table below:
Table 1.2

Area Tourism in the Kecamatan Gunung Kijang

\begin{tabular}{|c|c|c|}
\hline No & Lokasi Wisata & Potensi Wisata \\
\hline 1 & $\begin{array}{l}\text { Malang Rapat Jl. } \\
\text { Pantai Trikora }\end{array}$ & $\begin{array}{l}\text { Desa Wisata Padang Lamun } \\
\text { Malang Rapat ,Wisata Bahari }\end{array}$ \\
\hline 2 & $\begin{array}{l}\text { Teluk Bakau Jl. } \\
\text { Pantai Trikora }\end{array}$ & $\begin{array}{l}\text { Desa Wisata Padang Lamun } \\
\text { Teluk Bakau, Wisata Bahari }\end{array}$ \\
\hline 3 & $\begin{array}{l}\text { Teluk Bakau Jl. } \\
\text { Pantai Trikora }\end{array}$ & Pantai Trikora, Wisata Alam \\
\hline 4 & $\begin{array}{l}\text { Teluk Bakau Jl. } \\
\text { Pantai Trikora }\end{array}$ & Pantai Trikora, Wisata Alam \\
\hline 5 & $\begin{array}{l}\text { Teluk Bakau Jl. } \\
\text { Pantai Trikora }\end{array}$ & $\begin{array}{l}\text { Pulau Beralas Pasir,Wisata } \\
\text { Bahari }\end{array}$ \\
\hline 6 & $\begin{array}{l}\text { Teluk Bakau Jl. } \\
\text { Pantai Trikora }\end{array}$ & Gua Maria \\
\hline 7 & $\begin{array}{l}\text { Teluk Bakau Jl. } \\
\text { Pantai Trikora }\end{array}$ & Wisata Memancing \\
\hline 8 & $\begin{array}{l}\text { Teluk Bakau Jl. } \\
\text { Pantai Trikora } \\
\text { Trikora KM } 50\end{array}$ & $\begin{array}{l}\text { Kawasan Pariwisata Pantai } \\
\text { Trikora KM. } 50\end{array}$ \\
\hline 9 & $\begin{array}{l}\text { Teluk Bakau Jl. } \\
\text { Pantai Trikora } \\
\text { Trikora KM } 52\end{array}$ & $\begin{array}{l}\text { Pantai Trikora Kawasan } \\
\text { Pariwista KM. } 52\end{array}$ \\
\hline 10 & Kawal & $\begin{array}{l}\text { Wisata Mangrove, Wisata } \\
\text { Alam }\end{array}$ \\
\hline 11 & Kawal & $\begin{array}{l}\text { Bukit Kerang, Situs Cagar } \\
\text { Budaya }\end{array}$ \\
\hline 12 & Kawal & $\begin{array}{l}\text { Kampung Nelayan Kawal, } \\
\text { Wisata Budaya }\end{array}$ \\
\hline 13 & Galang Batang & Danau Biru, Wisata Alam \\
\hline
\end{tabular}

Source: Processed itself

One of village in the coastal island of Bintan and very close to the coastal tourist area is the village of Malang Rapat District of Gunung Kijang Bintan regency. But not much benefit, especially in the economic improvement of the local community. One factor is the village government has not been able to maximize the authority of the village so stir people's economy based on tourism. The village is located on the coast of Bintan Island is one of the many rural village in Bintan regency located in the coastal area precisely in the area Bintan Island Trikora beach tourism.

The phenomenon of the field indicates that Trikora beach tourism area is one of the tourist destinations of foreign and local, almost every time, especially the region's holiday travelers always attended by local and from abroad. Hotels, resorts and eat at the beach area is always visited by tourists. However, the majority of business owners of hotels, resorts and restaurants are owned and controlled by private parties. People living around the tourist area only gets as an employee but not as an owner. This is because the owners of land around the average tourist area controlled by the private sector instead of locals.

This causes the locals simply as spectators without optimally can utilize the environment for economic gains. To note exploit economic opportunities to increase revenue in the local economy is very large coastal resorts. People living around the coast can make their residence or their 
house as an inn /home stayslow cost, of course with the standard public toilet facilities as well as providing traditional cuisine. Because not all the tourists who are economically able to rent a hotel room, eat in expensive restaurants. Many also we find the traveler looking for lodging and culinary experience. Then people around the region could travel coast offers it, but today this model has not been found in Bintan regency, especially the village of Malang Rapat.

However, to provide insight to the level of practice to the public should be an effort of those who have the authority or the authority of the government in this regard is that village government is a governance structure that relates directly to the public. In the case of Bintan regency government should have a greater role through policies designed to support the village of Malang Rapat government sub-district Gunung Kijang Bintan regency in implementing village-owned authority to achieve these objectives. Hence the title of the researchers for this study isGovernment Policy Of District Bintan Icreasing The Ability Of Village In Managing The Authority (Study of Malang Rapat Rapat Village Authority in Managing Tourism Potential).

\section{Formulation of Problem}

In this study, the authors try to explain some of the problems that occurred in the village of Malang Rapat, especially regarding the implementation of the authority possessed by the village government in the public welfare, namely:

1. the village of Malang Rapat Government has not been able to develop and maximize the potential of the territory village near coastal resorts, particularly in a tourist village.

2. The village government has not been able to use the authority possessed by exploiting the existing potential to improve the welfare of society.

3. Lack of knowledge society in taking advantage of opportunities that are economically from the presence of the villages located close to the coastal resorts.

4. How policies implemented by local governments against the village to support the implementation of the village authority.

The study of the implementation of the authority of the village by the village government Malang Rapat District of Gunung Kijang Bintan regency is a very extensive study. Given the various limitations of the researchers only priority on:

1. Implementation of village authority carried out by the village government Malang Rapat harness the potential of villages that are geographically close to the coastal resorts.
2. How policies implemented by the local government in this regard Bintan district government in supporting the implementation of the village authority.

\section{The Objective and the purpose}

The purpose and objectives of this study are:

1. To see what is causing the village of Malang Rapat government has not been able to use the authority of the village have in improving the welfare of people living close to coastal resorts.

2. Discover what opportunities that can be done by the village administration in the public welfare in the village of Malang Rapat.

3. Discover what are the constraints experienced by the village of Malang Rapat government in the public welfare through the concept of rural tourism, particularly in the implementation of the village authority.

\section{THEORETICAL FRAMEWORK}

\section{Authority}

Authority or authority is associated with the legitimacy. According to Robert Bierstedt in his An Analysis of Social Power as saying that the authorityis institutionalized power. As said by Harold D. Lasswell and Abraham Kaplan is the power of formal authority. Someone who has the authority entitled to issue orders and regulations are entitled to receive and expect compliance with the regulations made.

The authority inherent in the position assumed by the person making it has the obligation and the need to provide command and run the existing rules. Implementation of authority possessed by the posts, is a fairness that needs to be obeyed and respected. Fairness in accordance with the principles and procedures that have been widely accepted in society.

Of course, the authority is a strong capital for the one who has the legitimacy of power in society. A leader or ruler who did not manage to use and take advantage of its authority confirmed as ruler failed, because the inherent authority of the facilities and services so that power can provide services and the right policies to lead.

A government without power inherent in itself not a rational government, because that government is powerless to regulate and organize and direct people want to carry around. Authoritative government power before the people. One source of power is the formal authority. The power that comes from one's position or positions in the organization. The power that comes from this position includes legitimate authority or control unauthorized sources including budget, personnel, infrastructure, information and ecological control resides in the organization he led. 
The authority obtained by someone can be obtained through(FA,M. Stroink and JG Steenbeek, as quoted by Ridwan HR):

1. attributive, which makes the granting authority of the law to the institutions or organs of government.

2. The delegation, delegation of authority from government organs to other government organs. Delegation is an earlier handover of responsibility is a responsibility that authorizes transferred to the receiving authority.

\section{Authority Villages}

Villages under Act No. 62014 is the legal community unit which has boundaries that are authorized to regulate and manage the affairs of government, the interests of the local community by community initiatives, terms of origin and or traditional rights are recognized and respected in the system of government of the Republic of Indonesia.

The village as a legal public entity or a public legal entity also has the authority though not as extensive authority possessed by the local government. Keweangan village is a village right to organize, manage and be responsible for government affairs and public interests. As is to organize, administer and government affairs and interests of the local community. Organize and manage the meaning is:

1. Extract and run the rules (regulations) on what is allowed and what not to do. For example banning villages set large truck entered the village street.

2. Responsible for planning, budgeting and undertake development activities or services, and resolve problems that arise. The development activities or services performed are activities that are a local authority such as Posyandu.

3. Decide and carry out the allocation of resources (both funds, equipment and personnel) in development activities or services, including sharing resources to beneficiaries.

4. Managing means operating, implementing, and taking care of the public properly. Implementation of development and public services is the concrete form of taking care of.

The village has the authority to regulate mainly against assets that belong to the village. Manage and organize here meant that manage and run the affairs given by the government to be referred to as a village or village management rights. For instance there is the village forest is owned by State and under the authority of the Ministry of Forestry, but the village can manage and benefit from the forest to the village needs to get permission from the Ministry of Forestry.

Authority of the village in question for the benefit of the local community. Government affairs basically covers three things; regulation, public services and community empowerment. The village government as the smallest entity of the State has the task of setting how to utilize public goods that could be used for the benefit of society.

Village authority by Ndraha $(2003 ; 85)$ is a legitimate power or the power or right delegated or given, the power to judge, act or command. The essence of this authority containing a political decision (allocation) and administrative decisions (implementation) which includes set up, administer, and responsibility.

According to the Development Team Academic Paper Undanng Draft Law On The village cited by Didik, 2010: 235 in (Solekhan: 2014) there are two main types of authority villages, namely:

1. The authority of origin recognized by the State; manage assets (natural resources, communal land, the land of the village treasury) within the territorial jurisdiction of the village, forming a village governance structure to accommodate the original order, resolve disputes and preserve traditional customs and local culture.

2. The authority attached (attribute set and manage the interests of local people local scale (village); planning and spatial development of the village, forming the structure and organization of the village administration, held village elections, forming a Village Consultative departement, manage APBDes, establish social institutions, develop BUMDes and so forth.

There are more kind of authority possessed by the village which is extra namely; the authority in the field of co-administration (delegation) provided by the government. the basic principle of the village only run the administrative tasks in the field of governance and development by the government.

Related with the village authorities are Government Regulation No. 43 of 2014 in article 33 of the Village neighbor explained that government affairs under the authority of the village include:

1. the authority based its origins rights;

2. local authority village scale;

3. the authority commissioned by the Government, estab ering provincial, or local government district / city; and

4. Other Authority commissioned by the government, provincial government, or local government district / city in accordance with the provisions of the legislation.

In the village authority to regulate and manage the purpose is addressed to government affairs and public interests. Government affairs basically covers three functions are run by the government, namely: setting(publicregulation),public services(publicgoods) andcommunity(publicempowerment). 
There are some important principles regarding the authority of the village namely:

1. Neither the origin nor the authority of the local authority is not the authority given by the government, nor the rest of the delegated by the City District Government as.

2. As a consequence of the village as the self-governing communities(self-governingcommunity), village authority in the form of set is limited to setting local interests and local communities within the boundaries of the village Adiministrasi.

3. Village authority on handling mainly oriented to the service of the citizens and community empowerment. For example, serve and finance the activities of the community farmer groups, specific skills training to the public, making the economy central to the community in order to strengthen local economics and so on.

4. In addition to regulate and manage, the village can also access government affairs under the authority of the District / Municipality to be used in meeting the needs of society.

There are some changes to the settings on the authority of the village between the Law No. 32 of 2004 by Law No. 6 of 2014 as to which are contained in the following table:

Table 2

The authority of the village according to Law No. 32 of 2004 and Act No 6 of 2014

\begin{tabular}{|c|c|}
\hline Law No. 32 of 2004 & Act No. 6 of 2014 \\
\hline $\begin{array}{l}\text { Affairs of governance } \\
\text { existing rights-based origins } \\
\text { of the village of }\end{array}$ & $\begin{array}{l}\text { the authority under the right } \\
\text { origin of }\end{array}$ \\
\hline $\begin{array}{l}\text { government affairs under the } \\
\text { authority of the District/State } \\
\text { submitted its settings to the } \\
\text { Village }\end{array}$ & authority scale local village \\
\hline $\begin{array}{l}\text { Co-administration } r \text { of } \\
\text { government, provincial } \\
\text { governments and or } \\
\text { District/Municipal } \\
\end{array}$ & $\begin{array}{l}\text { authority assigned by the } \\
\text { government, the government } \\
\text { provincial or local government } \\
\text { district/city }\end{array}$ \\
\hline $\begin{array}{l}\text { government affairs more by } \\
\text { legislation submitted to the } \\
\text { Village }\end{array}$ & $\begin{array}{l}\text { Authority of the other } \\
\text { commissioned by the } \\
\text { government, provincial } \\
\text { government, or the government of } \\
\text { Regency / city in accordance with } \\
\text { the provisions of the legislation }\end{array}$ \\
\hline
\end{tabular}

Source: Eko Sutoro, 2014

Authority the actual village not only includes the four items only. There is one more type of village authority, namely the inherent authority or often referred to as attributive authority which was not explicit in the Act No. 6 2014. As village government organization has a number of inherent authority (attributive) without explicitly mentioned in the list of village authority, namely:

1. Choosing the village head and village elections held
2. to establish and determine the composition of the personnel of the village

3. Holding village meetings

4. Develop and establish village planning

5. Develop and to establish and melaksananakan Budget rural

6. Develop, establish and implement village regulations

7. establish and develop institutions of the society and traditional institutions

8. to establish and run a village-owned enterprises (BUM Village)

Zakaria (in Eko 2010) mentions that the village authority as property righ community to regulate and manage their own household or often referred to as a form of genuine autonomy. There are several types of generic authority that is often discussed:

1. The authority to form and manage their own system of government.

2. The authority to manage local resources (land of the village treasury, crooked land, communal land, indigenous forests, etc.).

3. The authority to create and run local customs law.

4. The authority to manage and care for values and local culture (including customs)

5. authority of the judiciary or the judicial community(communityjusticesystem), for example in the resolution of local conflicts. In West Sumatra, for example there is a density agency Adat (KAN), which has the authority to carry out the judicial settlement of disputes especially pusako. As in Java, the name of the board morokaki which is a gathering of village elders container that serves as the input and consideration to the village head and serves as a customary dispute resolution.

Based on studies conducted by (Innesa Destifani et al) that the implementation of village authority is not appropriate between policy and implementation. As interior minister in the regulation number 30 of 2006 that the local government handed over several matters under the authority of the village one of which is in the business management of village tourism.

\section{Regional Government /Local Government}

Regional government is autonomous regional administration by the local government and the Regional Representatives Council (DPRD) based on the principle of decentralization. Government in these terms as well meaning as the action or activities to organize the administration in office environments. Under the law No. 32 of 2014 on local governments to function as an

Judging from the contents of autonomous regional government authority to organize two aspects of autonomy, 
which is the first full autonomy in which all the affairs and government functions to the content of substance or procedure for the organization of autonomy. Second, full autonomy is not only mastered the area of procedure for the organization but does not overwhelm the contents of the government. This matter is referred to as business tasks.

Villages in this case is a region located in the power of local government administration. The local government has a responsibility towards the progress of rural development. Therefore, the local government to make the village as a development priority by allocating funds from the budget of Regions to form village Village Allocation Fund (ADD). In chapters 18 and 19 of Law No. Village 62014 mentions one of the village authority assigned by the local government or the provincial government in accordance with the provisions of applicable law.

The assignment and the authority granted by the local government to the village include:

1. Operation of the village administration

2. village development Implementation

3. Guidance village society

4. empowerment of rural communities

in impementing the delegation of authority from local governments to the village to go through the regulations governor or regent / mayor as the legal basis for the authority. The local government has an obligation to conduct training and supervision to the village, because the indirectly village is subordinate to good local government governance structures and its territorial structure.

\section{RESEARCH METHODS}

The method used in this research is descriptive method with qualitative approach, a study that portray the actual state of the object under study, according to the actual circumstances at the time of the study. Therefore, this study method will portray the conditions of exercise of authority in the welfare of rural communities through the existing potential in the villages of travel.

This research was conducted in the village of Malang Rapat District of Gunung Kijang Bintan district with government research sites Desa Malang Rapat. Consideration of the location of this study that the village of Malang Rapat has great potential in the field of tourism with the location of the village located on the coast of white sand island of Bintan, which if utilized to its fullest potential will have a positive impact remarkable for its people but has not done optimally

informant in this study is the village administration Malang Rapat (village government and Village Consultative departement) and village leaders, Malang Rapat, and the parties related to the implementation of village authority that can evolve according to the needs of this study as subdistrict and district governments Bintan primary data obtained through techniques interviews conducted to stakeholders both located in the village of Malang Rapat or sub-district government and district government Gunung Kijang Bintan. While the secondary data obtained from the documents related to the study made. In addition, the data obtained through field observation in the village of Malang Rapat.

\section{THE OVERVIEW OF MALANG RAPAT VILLAGE}

VillageMalang Rapat is one of the villages in the province of Riau Islands precisely in the District Gunung Kijang Bintan regency. Desa Malang Rapat geographically located at an altitude of $0-20 \mathrm{~m}$ from sea level to the state average rainfall of $20 \mathrm{~mm} \mathrm{/} \mathrm{year,} \mathrm{and} \mathrm{the} \mathrm{average}$ temperature per year is $30^{\circ} \mathrm{C}$.

In the village of Malang Rapat administration is the region of the District Gunung Kijang Bintan regency. Desa Malang Rapat administratively restricted by neighboring villages and the sea. On the north bordering the Berakit village, south by the village of Teluk Bakau. West side adjacent to the Village North Tuopaya merupak while the eastern side of the South China Sea

Area of the village of Malang Rapat ie 771225 ha. The land area that is divided into multiple designation as for public facilities, residential, agricultural, economic activities, forests, beaches and others. From end to end within $18 \mathrm{KM}$ village consisting of $8 \mathrm{RT}$ and RW 3, where the distance to the capital of the District which is $15 \mathrm{KM}$ distance to the district capital, which is $12 \mathrm{KM}$ while the distance to the capital of the province that is $60 \mathrm{KM}$.

Access roads in the region of the village of Malang Rapat very nice there are only about $\pm 2 \mathrm{KM}$ less good but still able to be passed, along the way there are beaches and natural views of exotic, where there are tourist lodges and resorts along the coastline so much travelers who came in this area both foreign tourists and local tourists.

More geological characteristic form of sandy land so quite a lot of people who use the land to be used as a sand mine but there is also land suitable for agriculture whether it is managed by communities, groups as well managed by other parties are like oil palm plantations. Agricultural products, especially vegetables are very diverse and beyond to get consumed by the local community so that the results are widely sold in cape nut, agriculture is also very advanced group this can be proved by the plaque obtained by farmer groups. 


\section{IMPLEMENTATION OF THE AUTHORITY OF MALANGRAPAT VILLAGE GOVERNMENT ON THE TOURISM SECTOR}

Authority is an inherent right of an institution or position in an organization. The authority is to be able in the best use of them to achieve the desired goal. The village government of Malang Rapat in this case as a village that has tremendous natural potential, especially the tourism sector to try to take advantage of the authority is to create a prosperous rural communities through improving standards of living through community-based economic improvement or utilize the community-based tourism sector.

Village potential form of authority to this day have not been able to be done by the government and a maximum of the village, although the village has capital so strong political legitimacy with the village chief elected directly by the people. Village government should use the authority is able to make creativity and innovation in programs and activities to improve the living standards of rural communities. Plus the presence of Law No. 6 of 2014 on villages reinforce again that the village government should be the maximum in the management of the village.

In terms of revenue, the village has sufficient income promising sources of funds into the village treasury in the form of Budget Revenue Villages (APBDes) obtained from several sources such as the Village Fund Allocation (ADD), Village Fund (DD) and Revenue Villages (Pades), It is all the means and facilities which should if possible be utilized as will make the village which is synonymous with disadvantaged areas will become economically selfsufficient village.

However, some of the problems in the village such as limited human resources and less attention to national and local governments in coaching, empowerment and mentoring into all potential rural village especially those of the authority is not able to properly maximized.

Malan Rapat Village which has natural resources in the form of the potential of tourism to this day have not had the resources or the business units owned by the village. This can be seen from businesses in tourism carried out by the villagers. Almost all business units around the beach is owned by the private sector that directly is not good for the welfare of the local community. Except in the form of hotel and restaurant tax that goes to the local government. It researchers get when asked village officials who understand the condition, the village of Malang Rapat not yet have a business that is owned by the village.

Aside from the absence of a business unit owned by the village, the local community is also not able to exploit the tourism potential in front of their homes for being the object of the business in order to benefit in the form of money. Only the efforts that are not too large as a culinary but for the general public is not specific to tourists who come to the village.
There are several factors that cause societies, the village and the village government has been unable to exploit the potential of existing wsiata their area. Based on the facts on the ground researchers found several issues regarding the inability of the public and the government has not village manage the potential to improve the welfare of the community:

1. Minimum number of existing human resources in the villages.

Human resources is one of the main capital in creating a quality society. Human resources is also a measure of success in a human civilization. The quality of human resources are low it is common knowledge for rural communities. Lack of human resources here due to the low level of education received by the public and the lack of experience and skills possessed in economic management community. As a result, people do not have the exact sources of innovation in the new economy. Although they lie in front of a very abundant natural resources, it can be seen from the innovation and creativity of the community in making the business units related Attraction with beaches like home stay or lodging house with a natural concept that a low-cost complete with its traditional culinary. Utilizing a fishing tackle in the village of Malang Rapat like Kelong to be power Pull for tourists to visit and there are many more potential that can be developed.

Because of the lack of experience and lack of education result inworldview an instant became the dominant public life. They always use the old way of making a living, people can not create new things. Because new things are always scary for the villagers. In addition to low resource poor communities apparatuses village is also a major factor in creating the progress of the village. Not many innovations that emerged from the village government, even if there are only normal and has little to do with the existing tourism potential.

Even if there are sons and daughters village has a good level of education that they do not want to go back to the village to build the village with the knowledge that they have, they prefer a career in other places in the city are nearby. Their parents were also more than happy their children to work instead of working elsewhere in the hometowns that notabenenya work fishermen. The public perception that says working in the village is not a good status in the community become one of the causes of the minimum qualified personnel in the village.

\section{Low apparatuses village}

field Based on the findings the researchers found that poor village meetings was minimal innovation of the village government to conduct economic improvement of society by utilizing the existing natural potential. It can be seen from the village regulation with regard to the tourist-based business units, there is no village-owned enterprises that manage business units based travel. This can be ascertained 
that the village government has not had an idea and the concept of economic management that can improve people's welfare. They are always thinking instant classic and so hesitate and falter when put through something new that they have never done. If there is any new ideas and concepts in the management of travel based on economy, the villagers have not been able to do it because it has not yet qualified expertise. Resulting in a program does not last long because of many obstacles and pitfalls.

\section{The lack of attention of the government in fostering to the village}

Another factor that is important is causing the village government has not yet taken its authority is the lack of government attention to this. Both central and local governments. Based on the findings in the field of rural communities that lack of government guidance and empowerment of the rural population. While there are tentative coaching was just not sustainable. The government is more cederung make physical assistance program to the community of the mental aspect of coaching in the community.

Assistance given usually fishing gear and the like, the government rarely provides coaching and mentoring in aspects of the formation of a new business unit in accordance with the existing tourism potential in the villages. As a result, many government programs that are not on target in accordance with the needs of the community. Based issue for society it is the perception of something, so much needed guidance and assistance. The district government is merely making rules that bestow regent to subdistrict authorities to commit guidance to the village. But in reality many programs and coaching are not significantly impact on the welfare of the community.

\section{The policy of Bintan Regency Government in strengthening the implementation of village authority}

as stipulated in law Act 6 of 2014 about the village that the village was given authority so broad in managing yourself so in the hope of creating a better economy to the society. But a lot of field data that we find the village government and community is still difficult to realize the mandate of the law. Factors that cause it to be one of them is not maximal guidance and supervision of the local government to the village. As an institution that is authorized to conduct training and empowerment of the rural population is considered not up to the local government do to ensure theobligations village authority goes well. As delegated in legislation village No. 6 In 2014 the government above the provincial and district cities can provide delegation of authority to the village to manage their own areas.
But there are still local government attention given to rural districts in particular Bintan Village Allocation Fund (ADD) sourced from the budget of Bintan large enough is given to village in the district of Bintan. In addition many physical assistance in the form of gear fishermen, capital assistance for the creative economy and so on. However, such assistance is still tentative and accidental, did not touch the issue of mental and character. Help and also many programs are not well targeted, it is well known that the village of Malang Rapat has great tourism potential local and foreign wistawan many who visit the beaches located along the village. Policies and programs of the local government that encourages villages to be independent and creative recognized by the public was miniuml. As a result, the natural potential can only be enjoyed by sight but not a hedge to a sustainable economy.

The local government through regulation Bintan regent megenai already issued rules for the delegation of authority to the sub-district to provide guidance to the village of how the village can be independent and innovative in taking care of his own household. But until now the impact has not been felt by the community. On the other hand people expect the role and intervention of local governments in the form of coaching and mentoring is needed. People need teaching point for limitation of human resources owned by both societies and village officials. People need to be guided mentally and character, for an instant and quick thinking so is the hallmark of the village community. Then the development and formation of the character of the community should be the government's attention.

Especially for Bintan regency tourism sector has made a good plan, as stated in the Book of Regional Tourism Development Master Plan 2015-2025 of Bintan year, with the increase of tourism facilities and infrastructure, increased marketing of tourism products, travel industry and tourist institutions. The program is also a tourist village strategic plan of the Department of Tourism Bintan regency in 2016-2021, but the problem is in the realm of implementing policy and plans must be made in accordance with the conditions of rural communities.

Attention and desire district government in rural development is very large, but weak in terms of concept, planning and execution which ultimately affect the way in place of rural development. In particular the exercise of authority by the government of the village.

\section{CONCLUSION}

Improving the quality of life in the various sectors is the obligation for state o run. Attendance Law No. 6 of 2014 the village was the spirit and ideals of the country to create the conditions for a better village. Improving the quality of life of rural communities is a snowball to the advancement of the country. Therefore, development of villages should be the main priority of both central government and local 
governments. Village authority which has not been run up by the village government is a challenge for central and local government to make an evaluation and introspection government. Owned village authority has not been able to bring the village to better.

Malang Rapat Village is one of the villages in the district of Bintan with natural potential outstanding beach has not been fully utilized for the benefit of society, if the authorization is done well of course potential around the village or who owned the village can be used for the benefit of the community, especially to improve the welfare of society. Many factors cause it happens starting from the low human resources in villages, village officials and local government policies have not been able to explore the spirit and knowledge of the community in implementing authority.

Therefore the local government should be sensitive to this issue, should always build communication with the community. Find out the desire and needs of the community, understand the character of the community. The government should also have a clear concept in the construction of the village, select and prioritize village that has the potential to be developed. so much benefit that can be taken. Perform periodic coaching to involve other institutions such as universities, NGOs and others who focus on rural development. If all that is done then the public welfare will be realized.

\section{REFERENCES}

[1] Bungin, Burhan, 2014, Penelitian Kualitatif, Kencana, Jakarta.

[2] Destifani, Innesa, dkk, Pelaksanaan Kewenangan Desa dan Mewujudkan Otonomi Desa (Studi Desa Sumber Kecamatan Kradenan Kabupaten Blora), Jurnal Adinistrasi Publik Vol 1 No 6)

[3] Fadli, Moh, dkk, 2013, Pembentukan Peraturan Desa Partisifatif (Head To A Good Village Governance), UB Press, Malang.

[4] Halim, Abdul, 2014, Politik Lokal, LP2B, Yogyakarta.

[5] Simanjuntak, Bungaran Antonius dan Soedjito Sosrodiharjo, 2014, Metode Penelitian Sosial, Yayasan Pustaka ObOR Indonesia, Jakarta.

[6] Sutoro, Eko, dkk. Desa Membangun Indonesia. 2014. FPPD, Yogyakarta.

[7] Zubaedi, 2013, Pengembangan Masyarakat Wacana dan Praktik, Kencana, Jakarta.

[8] Undang-Undang Republik Indonesia Nomor 6 Tahun 2014 tentang Desa.

[9] Peraturan Pemerintah Nomor 43 Tahun 2014 tentang Desa. 